\title{
RESOLUTION OF DL-PENTAMETHYLPHENYLALANINE
}

\author{
G. I. Tesser, H. G. A. Slits and J. W. van Nispen \\ Department of Organic Chemistry, University of Nijmegen, \\ Toernooiveld, Nijmegen, The Netherlands
}

Received 27 October 1972

\begin{abstract}
The synthesis of $N$-acetyl-DL-pentamethylphenylalanine and its resolution with brucine are described. Assignment of the configuration of both antipodes was performed with O.R.D.-measurements and checked by enzymic hydrolysis.
\end{abstract}

Carrión et al. (1) have synthesized a derivative of phenylalanine in which the phenylring had been permethylated. This amino acid resembles tryptophan in its electron-donor properties. In order to find a possible role of tryptophan as an electron-donor in biologically active peptides, one might consider replacement of the latter by this amino acid as a "functional analogue". A prerequisite to this application is that the analogue be resolved into its antipodes, the configuraons of which are known.

\section{MATERIALS AND METHODS}

Because the synthesis which is given by Carrion et al. (1) was conducted via an acetamidomalonate, we decided to prepare $\mathrm{N}$-acetyl-pentamethylphenylalanine by partial hydrolysis and decarboxylation of this intermediate and to investigate its resolution by enzymic or chemical methods. The turnover of enzymic hydrolysis with carboxypeptidase A (2) proved impracticably slow $(0.5 \mu \mathrm{mol} / \mathrm{mg} / \mathrm{h})$ for a usable resolution. The enzymic hydrolysis could be used, however, for corroboration of the eventually assigned configuration. For chemical resolution several bases, $(-)$ ephedrine, $(+)$ dexamphetamine, quinine and brucine were attempted. It turned out that only the brucine salts of the acetylated antipodes differed sufficiently in solubility to obtain good resolution.
A favorable feature of the procedure was the independent crystallizability of both diastereomeric salts from different solvent systems once they had been roughly separated. So ethyl acetate/propanol-2 dissolves preferably the salt containing the dextrorotating acid, and methanol the other. Methanol also is an excellent solvent for the mixture of both salts. Thus, the fundamental problem in chemical resolutions concerning the stereochemical purity of the "second, better soluble" fraction did not arise in this case.

Decomposition of both diastereomeric salts was carried out with an excess of hydrochloric acid in propanol-2. When a primary alcohol was used, partial esterification occurred rapidly. The antipodes were isolated in nearly theoretical yield, and their absolute specific rotations were equal within the limits of experimental error.

Hydrolysis of the acetylated antipodes was performed by heating their solutions in acetic acid with concentrated aqueous hydrochloric acid under reflux. In both cases the product crystallized on cooling in the form of its monohydrochloride monohydrate. (On drying in a high vacuum at $80^{\circ} \mathrm{C}$ over $\mathrm{P}_{2} \mathrm{O}_{5}$, efflorescence was observed and the hydrochloride was left. In moist air the hydrate reconstituted itself.) Treatment of its solution in acetic acid with ammonium acetate gave the neutral amino acid.

As the deacetylation procedure was rather drastic, the risk of partial racemization at this 
step is not merely imaginary. Extensive racemization could be ruled out by reacetylation of a sample: the rotation for the product appeared to be unaltered.

The resolution was performed twice, with different batches of brucine. The results confirmed each other.

Assignment of the configuration was performed by rotatory dispersion measurements (3). Positive Cotton effects were recorded for dextrorotating $\mathrm{N}$-acetyl-pentamethylphenylalanine as well as for N-acetyl-L-phenylalanine and Lphenylalanine. The $(+)$-enantiomer was also susceptible to enzymic attack: digestion with carboxypeptidase $\mathbf{A}$, although very slow, resulted in precipitation of the free amino acid after one day of incubation. The optical rotatory dispersion curve of the precipitated amino acid revealed also a positive Cotton effect. The levorotating enantiomer was not digestible with carboxypeptidase A.

From these observations we attribute L-configuration to $(+)$-acetyl-pentamethylphenylalanine and D-configuration to its enantiomer. As deacetylation did not alter the sign of the rotation, dextrorotatory pentamethylphenylalanine has to be looked upon as belonging to the class of amino acids having "natural" asymmetry.

\section{EXPERIMENTAL PROCEDURES}

Melting points were determined with a Heiztisch Microscope (Leitz) and are uncorrected. Specific rotations and O.R.D. curves were measured with a Perkin Elmer 141 and a Jasco O.R.D./U.V.-5 instrument. N.M.R. Spectra were recorded on a Varian HA 100 apparatus and were in accordance with theory.

For thin layer chromatography on silica, precoated plates (Kieselgel $F_{254}$, Merck) (TS) were used with the solvent systems $A=$ benzene-acetone (1:1), $B=n$. butanol-acetic acid-water $(10: 1: 3)$, $\mathrm{C}=$ ethyl acetate-pyridine-acetic acid-water (62:21:6:11) and $\mathrm{D}=$ acetic acid- $0.1 \mathrm{~N}$ hydrochloric acid $(4: 1)$. The chromatograms were developed according to Reindel \& Hoppe (4) with chlorine and $o$. tolidine as spray reagents (5).

\section{Pentamethylbenzylchloride}

Bis(chloromethyl)mesitylene was synthesized from mesitylene by chloromethylation, according to Shacklett \& Smith (6). The compound was recrystallized from acetic acid and was obtained in
$78 \%$ yield. M.p. $103-105^{\circ} \mathrm{C}$. It contained some $6 \%$ of tris(chloromethyl)mesitylene.

The product was hydrogenated in acetic acid with palladium on charcoal as a catalyst. On concentration of the filtered solution, some hexamethylbenzene crystallized. Pentamethylbenzene, contaminated with 2 to $3 \%$ hexamethylbenzene (N.M.R.), was obtained in $94 \%$ yield.

Without further purification, the compound was chloromethylated according to Carrión (1). The product was recrystallized from $90 \%$ acet acid yielding $85 \%$ of pure pentamethylbenzy ${ }_{1-}$ chloride with m.p. $82-84^{\circ} \mathrm{C}$.

Analysis:

$\mathrm{C}_{12} \mathrm{H}_{17} \mathrm{Cl}$ Calcd.: $\% \mathrm{C} 73.27 \% \mathrm{H} 8.71 \% \mathrm{Cl} 18.02$

(196.72) Found: \% $73.55 \% \mathrm{H} 8.92 \% \mathrm{Cl} 18.15$

\section{Diethyl-(2-pentamethylbenzyl-2-acetamido)malo- nate}

This intermediate was synthesized according to Carrión (1). The product was purified either by recrystallization from $70 \%$ acetic acid, giving large rectangular plates, or by treatment with hot methanol-water. The yield was $70 \%$ m.p. $133-135^{\circ} \mathrm{C}$, TS: $\mathrm{Rf}=0.60$, system A.

Analysis:

$\mathrm{C}_{21} \mathrm{H}_{31} \mathrm{NO}_{5}$ Calcd.: $\% \mathrm{C} 66.82 \% \mathrm{H} 8.28 \% \mathrm{~N} 3.71$

(377.48) Found: $\% \mathrm{C} 66.68 \% \mathrm{H} 8.28 \% \mathrm{~N} 3.66$

If the reaction mixture contains some water the alkylation of the malonate is not impaired, but the product isolated is $\mathrm{N}$-acetyl-DL-pentamethylphenylalanine ethyl ester, melting at $142-143^{\circ} \mathrm{C}$ rather than the malonate. This was confirmed $b$, azeotropic esterification of N-acetyl-DL-pentamethylphenylalanine with ethanol. N.M.R. spectroscopy revealed identity of both compounds. $\mathrm{TS}: \mathbf{R f}=0.51$, system $\mathrm{A}$.

\section{$N$-Acetyl-DL-pentamethylphenylalanine}

By alkaline hydrolysis and decarboxylation of the foregoing compound, the racemic pentamethylphenylalanine derivative was obtained. Therefore, diethyl-(2-pentamethylbenzyl-2-acetamido)malonate was dissolved in a mixture of dioxane and water (2:1). A solution of $4 \mathrm{~N}$ sodium hydroxide (about $20 \%$ excess) was added, and the solution refluxed for about $18 \mathrm{~h}$. Dioxane was removed under reduced pressure and the resulting solution extracted with ethyl acetate to remove some $5 \%$ of unreacted starting material which was recycled. The aqueous layer was poured into an excess of $6 \mathrm{~N}$ hydrochloric acid with stirring, then cooled and filtered. After recrystallization from $90 \%$ 
acetic acid, about $96 \%$ of chromatographically pure product was obtained, m.p. $247-248^{\circ} \mathrm{C}$, TS: $\mathrm{Rf}=0.67$, system $\mathrm{B} ;=0.81$, system $\mathrm{C}$. Analysis:

$\mathrm{C}_{16} \mathrm{H}_{23} \mathrm{NO}_{3}$ Calcd.: $\% \mathrm{C} 69.29 \% \mathrm{H} 8.36 \% \mathrm{~N} 5.05$

(277.36) Found: \% $68.88 \% \mathrm{H} 8.49 \% \mathrm{~N} 4.99$

\section{Resolution of N-acetyl-DL-pentamethylphenylala-} nine

Because of the limited solubility in the solvent 'stem used for the resolution, $65.0 \mathrm{~g}=234.3$ .timol of $\mathrm{N}$-acetyl-DL-pentamethylphenylalanine and $92.3 \mathrm{~g}=234.3 \mathrm{mmol}$ of brucine were dissolved in $650 \mathrm{ml}$ of warm methanol. The solvent was removed by evaporation, and evaporation was repeated after the addition of some propanol2 to eliminate residual methanol. The residue containing the diastereomeric brucine salts was dissolved in $300 \mathrm{ml}$ of warm propanol-2, the same volume of ethyl acetate was added and the solution stored in a refrigerator for 7-8 d. After filtration and washing of the precipitate (I) with ethyl acetate, the combined filtrates were evaporated to dryness, the residue taken up in ethyl acetate and the solvent evaporated again. To remove the last traces of propanol-2 this procedure was repeated. The residue was dissolved in some $300 \mathrm{ml}$ of warm ethyl acetate, the solution cooled and kept at about $0^{\circ} \mathrm{C}$ for 1 week. A small amount of precipitate (II) was filtered and the filtrate evaporated to dryness. Upon dissolution of the residue in $300 \mathrm{ml}$ of warm lethanol immediate crystallization occurred upon cooling, giving fraction III.

Fractions I and III were recrystallized from ethyl acetate/propanol-2 (1:1) and methanol, respectively.

\begin{tabular}{|c|c|c|c|}
\hline $\begin{array}{l}\text { Frac- } \\
\text { tion }\end{array}$ & Yield & M.p. & $\begin{array}{c}{[\alpha]_{\mathrm{D}}^{2 \alpha}} \\
(\mathrm{c}=1, \mathrm{MeOH})\end{array}$ \\
\hline
\end{tabular}

\begin{tabular}{lrrrr} 
I & $69.2 \mathrm{~g}=43.9 \%$ & $216-218^{\circ} \mathrm{C}$ & $-16.0^{\circ} \pm 0.5^{\circ}$ \\
II & $2.5 \mathrm{~g}=1.6 \%$ & $130-240^{\circ} \mathrm{C}$ & $-2.4^{\circ} \pm 0.5^{\circ}$ \\
III & $57.8 \mathrm{~g}=36.7 \%$ & $129-134^{\circ} \mathrm{C}$ & $-6.2^{\circ} \pm 0.5^{\circ}$ \\
\hline
\end{tabular}

\section{$N$-Acetyl-L-pentamethylphenylalanine}

In $200 \mathrm{ml}$ of propanol-2 were dissolved $54.84 \mathrm{~g}$ of the brucine salt III $(80.3 \mathrm{mmol})$. Fifty $\mathrm{ml} 4 \mathrm{~N}$ hydrochloric acid $(200 \mathrm{mmol})$ were added with stirring followed by ca. $1300 \mathrm{ml}$ of water. After cooling, the precipitate was filtered, washed with dilute hydrochloric acid and dried.
Yield: $21.05 \mathrm{~g}=94.5 \%$ of a chromatographically pure product (TS: $R f=0.80$, system C). M.p.: $246-248^{\circ} \mathrm{C}$. (The crystals melted at about $222^{\circ} \mathrm{C}$, but then suddenly gave long thin needles, which melted again at $246-248^{\circ} \mathrm{C}$ ).

$[\alpha]_{\mathbf{D}}^{21}=15.8 \pm 0.5^{\circ}(\mathrm{c}=1, \mathrm{MeOH}) ;[\alpha]_{\mathrm{678}}=$ $16.7^{\circ},[\alpha]_{546}=19.3^{\circ},[\alpha]_{436}=38.0^{\circ},[\alpha]_{365}=74.2^{\circ}$. Analysis:

$\mathrm{C}_{10} \mathrm{H}_{23} \mathrm{NO}_{3}$ Calcd.: $\% \mathrm{C} 69.29 \% \mathrm{H} 8.36 \% \mathrm{~N} 5.05$

(277.36) Found: \%C $69.24 \% \mathrm{H} 8.47 \% \mathrm{~N} 5.00$

$\mathrm{N}$-Acetyl-D-pentamethylphenylalanine was obtained from its brucine salt (1) in a similar manner in $88 \%$ yield. M.p.: $242-245^{\circ} \mathrm{C}$. (The crystals melted at about $218^{\circ} \mathrm{C}$, giving long thin needles which melted again at $242-245^{\circ} \mathrm{C}$ ).

$[\alpha]_{\mathrm{D}}^{21}=-16.0^{\circ} \pm 0.5^{\circ}(\mathrm{c}=0.98, \mathrm{MeOH}) ;$

$[\alpha]_{578}=-16.5^{\circ},[\alpha]_{648}=-19.4^{\circ},[\alpha]_{436}=-38.1^{\circ}$, $[a]_{365}=-74.4^{\circ}$.

Analysis: Found: $\%$ C $69.29 \% \mathrm{H} 8.54 \% \mathrm{~N} 5.01$

\section{L-Pentamethylphenylalanine monohydrochloride monohydrate}

The N-acetyl compound $(20.03 \mathrm{~g}=72.2 \mathrm{mmol})$ was dissolved in $200 \mathrm{ml}$ of concentrated aqueous hydrochloric acid and $200 \mathrm{ml}$ of glacial acetic acid, and the solution refluxed for $5 \mathrm{~h}$. When heating was discontinued crystallization started at once, and $20.37 \mathrm{~g}=97.5 \%$ of $\mathrm{H}-\mathrm{L}-\mathrm{Phe}(\mathrm{Me})_{5}-$ $\mathrm{OH} . \mathrm{HCl} . \mathrm{H}_{2} \mathrm{O}$ could be isolated. TS: $\mathrm{Rf}=0.50$, system D. M.p. : $256.5-258^{\circ} \mathrm{C}$.

$[\alpha]_{\mathrm{D}}^{21}=55.2^{\circ} \pm 0.5^{\circ}(\mathrm{c}=0.59$, HOAc $+0.1 \mathrm{~N}$ $\mathrm{HCl}(4: 1)) ;[\alpha]_{578}=57.2^{\circ},[\alpha]_{648}=65.8^{\circ},[\alpha]_{436}=$ $120.9^{\circ},[\alpha]_{365}=211.8^{\circ}$.

Analysis: $\mathrm{C}_{14} \mathrm{H}_{24} \mathrm{NO}_{3} \mathrm{Cl}(289.80)$

Calcd.: $\% \mathrm{C} 58.02 \% \mathrm{H} 8.35 \% \mathrm{~N} 4.83 \% \mathrm{Cl} 12.23$

Found: \% $57.83 \% \mathrm{H} 8.34 \% \mathrm{~N} 4.73 \% \mathrm{Cl} 12.36$

The same procedure was used to get the Disomer, m.p. $254.5-256^{\circ} \mathrm{C}$. $[\alpha]_{\mathrm{D}}^{21}=-54.9 \pm 0.5^{\circ}$ $(\mathrm{c}=0.64, \mathrm{HOAc}+0.1 \mathrm{~N} \mathrm{HCl}(4: 1)) ;[\alpha]_{578}=$ $-57.0^{\circ},[\alpha]_{548}=-65.7^{\circ},[\alpha]_{438}=-120.3^{\circ},[\alpha]_{385}$ $=-211.3^{\circ}$.

Analysis: Found: $\%$ C $57.88 \% \mathrm{H} 8.34 \% \mathrm{~N} 4.74 \% \mathrm{Cl} 12.42$

\section{L-Pentamethylphenylalanine}

The neutral amino acid was obtained from its hydrochloride upon dissolution in hot acetic acid $(100 \%$, addition of an excess of ammonium acetate, and dilution with water. Consistent analytical data were obtained after thorough drying $\left(80^{\circ} \mathrm{C}\right.$ in high vacuum for about $\left.6 \mathrm{~h}\right)$. M.p.: $242-$ 
$245^{\circ} \mathrm{C},[\alpha]_{\mathrm{D}}^{21}=65.7 \pm 0.5^{\circ}(\mathrm{c}=0.46$, HOAc +0.1 $\mathrm{N} \mathrm{HCl}(4: 1)) ;[\alpha]_{678}=68.8^{\circ},[\alpha]_{546}=78.5^{\circ},[\alpha]_{436}$ $=144.7^{\circ},[\alpha]_{365}=254.4^{\circ}$.

Analysis:

$\mathrm{C}_{14} \mathrm{H}_{21} \mathrm{NO}_{2}$ Calcd.: $\% \mathrm{C} 71.46 \% \mathrm{H} 9.00 \% \mathrm{~N} 5.95$

(235.33) Found: $\%$ C $71.51 \% \mathrm{H} 9.06 \% \mathrm{~N} 5.90$

The same procedure was used to get after drying the D-isomer, m.p. $243-246^{\circ} \mathrm{C}$. $[\alpha]_{\mathrm{D}}^{21}=-65.4$ $\pm 0.5^{\circ} \quad(\mathrm{c}=0.47, \mathrm{HOAc}+0.1 \mathrm{~N} \mathrm{HCl}(4: 1))$; $[\alpha]_{578}=-68.3^{\circ},[\alpha]_{546}=-78.1^{\circ},[\alpha]_{436}=-144.0^{\circ}$, $[a]_{365}=-254.3^{\circ}$.

Analysis: Found: \%C $71.17 \% \mathrm{H} 8.96 \% \mathrm{~N} 5.82$

\section{ACKNOWLEDGMENTS}

We are grateful to Professor Dr. R. J. F. Nivard for his kind interest in this work.

The expert assistance of Mr. J. Diersmann who performed the elemental analyses and Mrs. L. van Herpen who recorded the N. M. R. spectra is also gratefully recognized.

The work was carried out under the auspices of the Netherlands Foundation for Chemical Research (SON) and with financial aid of the Netherlands
Organization for the Advancement of Pure Research (ZWO).

\section{REFERENCES}

1. Carrión, J. P., Deranleau, D. A., Donzel, B., ESKo, K., MoSER, P. \& SCHWYZER, R. (1968) Helv. Chim. Acta 51, 459-481.

2. GreEnsteIn, J. P. (1954) Advances in Protein Chemistry, Vol. 9 p. 121, Academic Press, New York.

3. Dirkx, I. P. \& Sixma, F. L. J. (1964) Rec. Trav. Chim. 83, 522-534.

4. ReIndel, F. \& Hoppe, W. (1953) Naturwisse. schaften 40, 221.

5. STAHL, E. (1962) Dünnschichtchromatographie p. 501, Springer-Verlag, Berlin.

6. Shacklett, C. D. \& Sмith, H. A. (1951) J. Amer. Chem. Soc. 73, 766-768.

7. Braun, J. von \& Nelles, J. (1934) Chem. Ber. 67, 1094-1099.

Address:

G. I. Tesser

Department of Organic Chemistry

University of Nijmegen

Toernooiveld, Nijmegen

The Netherlands 